\title{
Droughts and governance impacts on water scarcity: an analysis in the Brazilian semi-arid
}

\author{
A. C. S. Silva ${ }^{1}$, C. O. Galvão ${ }^{1}$, and G. N. S. Silva ${ }^{2}$ \\ ${ }^{1}$ Federal University of Campina Grande, Campina Grande, 58429-900, Brazil \\ ${ }^{2}$ Federal University of Pernambuco, Recife, 50670-901, Brazil \\ Correspondence to: A. C. S. Silva (ccristina24@yahoo.com.br)
}

Received: 16 April 2015 - Accepted: 16 April 2015 - Published: 11 June 2015

\begin{abstract}
Extreme events are part of climate variability. Dealing with variability is still a challenge that might be increased due to climate change. However, impacts of extreme events are not only dependent on their variability, but also on management and governance. In Brazil, its semi-arid region is vulnerable to extreme events, especially droughts, for centuries. Actually, other Brazilian regions that have been mostly concerned with floods are currently also experiencing droughts. This article evaluates how a combination between climate variability and water governance might affect water scarcity and increase the impacts of extreme events on some regions. For this evaluation, Ostrom's framework for analyzing social-ecological systems (SES) was applied. Ostrom's framework is useful for understanding interactions between resource systems, governance systems and resource users. This study focuses on social-ecological systems located in a drought-prone region of Brazil. Two extreme events were selected, one in 1997-2000, when Brazil's new water policy was very young, and the other one in 2012-2015. The analysis of SES considering Ostrom's principle "Clearly defined boundaries" showed that deficiencies in water management cause the intensification of drought's impacts for the water users. The reasons are more related to water management and governance problems than to drought event magnitude or climate change. This is a problem that holdup advances in dealing with extreme events.
\end{abstract}

\section{Introduction}

Drought is a recurrent extreme climate event over land that is characterized, over a period of months to years, by belownormal precipitation and it is occurring during the last millennium in many parts of the world (Dai, 2011). Extreme events, such as droughts, might produce impacts on society, due to reduction in water availability. However, the impact of extreme events is not only dependent on their hydrological characteristics, but also on management and governance.

This article aims to analyse how a combination between climate variability and water governance might affect water scarcity and increase the impacts of extreme events on some regions, by applying Ostrom's framework for analyzing Social-Ecological Systems.

Elinor Ostrom contributed for the understanding of how society might influence the sustainability of natural resources. Ostrom's effort "turned to identifying eight underlying design principles that characterized robust common- property institutions" (Ostrom, 2005) and established a framework to analyse social-ecological systems (Ostrom, 2007, 2009).

Huntjens et al. (2012) refined and extended Ostrom's institutional design principles for local common pool resources systems (Ostrom, 1990, 2005) to understand the governance of adaptation to climate change in complex water systems, as water basins. Silva et al. (2013) and Silva (2014) adapted Huntjens and Ostrom principles to analyse the institutional water governance in Brazil for the adaptation to climate variability and change, considering also Ostrom's framework for analyzing social-ecological systems (Anderies et al., 2004; Ostrom, 2007, 2009).

Anderies et al. (2004) refer to Social-Ecological-System (SES) as "the subset of social systems in which some of the interdependent relationships among humans are mediated through interactions with biophysical and non-human biological units". A combination between Huntjens' adapta- 
tion and the original Ostrom's principles for analyzing complex systems are interesting for identifying problems in water governance and management.

The analysis focuses on social-ecological systems located in a drought-prone region of Brazil. The semi-arid region of Brazil is vulnerable to extreme events, especially droughts, for centuries. Water reservoirs are the most important water sources to supply urban and rural areas in that region. In 2012, a new dry period was installed, which persists until 2015, so that the water storage of those reservoirs is still declining. Two different extreme events were selected for analysis, the first one starting in 1997, when Brazil's new water policy was very young, and the second one starting in 2012.

Ostrom's institutional first design principle "Clearly defined boundaries" was selected for this analysis, because the noncompliance or compliance with this principle might be determinant for social-ecological systems under stress, such as droughts.

\section{Case study}

The study area is located in the State of Paraíba, in the semi-arid north-eastern region of Brazil, comprising two river basins, namely Paraíba and Piancó-Piranhas-Açu (PPA) (Fig. 1). In the last century, several reservoirs were built to cope with droughts in this area. Four federal reservoirs for water accumulation with capacities ranging from 80 to $1358 \mathrm{hm}^{3}$ were analysed in this study. The reservoirs have multiple uses, among them drinking water supply of some mayor cities. For example, the Epitácio Pessoa reservoir is used for water supply for around 500000 inhabitants and Coremas/Mãe d'Água is responsible for the drinking water supply of about 400000 inhabitants.

The Brazilian Water Policy and its National Management System were established in 1997. The National Management System is composed, in the case study, by the National Water Agency, the State Water Agency of Paraíba, the Water Basin Committees of Paraíba River and Piancó-PiranhasAçu River, the National and State of Paraíba's Water Councils. The National Water Agency is responsible for the implementation of the water management instruments in the studied reservoirs, since they were constructed by a Federal Department.

\section{Methodology}

Ostrom (2007) established a framework for social-ecological systems: "analysis of how attributes of a resource system, the resource units generated by that, the users of that system, and the governance system jointly affect and are indirectly affected by interactions and resulting outcomes achieved at a particular time and place". This framework "enables one to organize how these attributes might affect and be affected by the larger socioeconomic, political, and ecological settings in

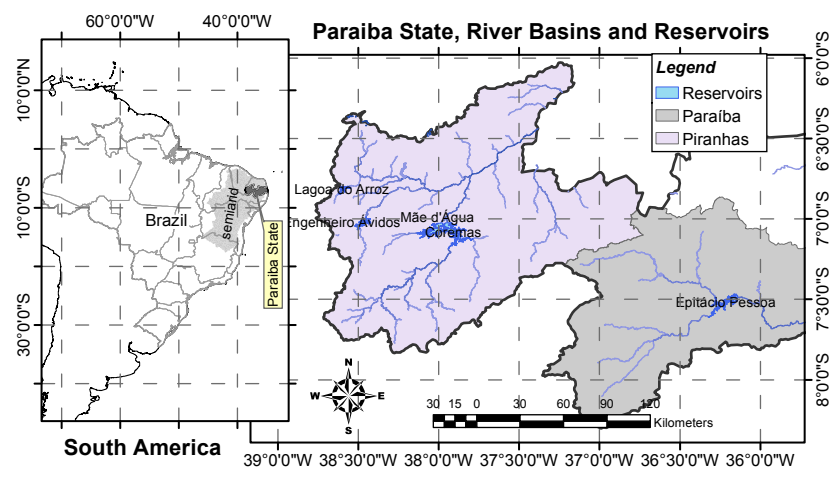

Figure 1. Study area: the State of Paraíba in the Brazilian semi-arid, the Paraíba and Piancó-Piranhas-Açu River Basins and the water reservoirs.

which they are embedded, as well as smaller ones" (Ostrom, 2007).

For the present analysis, the institutional design principle "clearly defined boundaries" is taken as reference to understand the extreme events and their impacts on the case study. The investigation of this Ostrom's institutional design principle in the SES can show noticeably how poor water governance might increase the impacts of extreme events on some regions. Originally, Ostrom (1990, p. 91) defined this principle as "individuals or households who have rights to withdraw resource units from the common-pool resource (CPR) must be clearly defined, as must the boundaries of the CPR itself". Huntjens et al. (2012, p. 70) defined it as "completeness of water-user stakeholders in the adaptation process and clarity about who has rights to use water resources in the case of droughts".

For this analysis, this principle is investigated in terms of adaptation to climate variability, that is, who has the right to use water, not only in times of drought, but also in rainy periods. The limits of the resources themselves are also investigated in the analysis, as originally proposed by Ostrom.

This analysis identified the components of the SES for the study case and investigated the principle "clearly defined boundaries" considering the water governance of Brazil. The evaluation of the principle, in this study case, considered whether there are "clearly defined boundaries": How much water can be withdrawn with full guarantee in drought periods? Who are the water users and how much water are they allowed to withdraw? Are there water quality restrictions according to the water uses?

According to Ostrom $(1990,2005,2007,2009)$ and Anderies (2004) the principle and the SES might change according to the object of analysis and its aim. The ecological setting is considered, here, as the climate variability scenarios, specifically the drought extreme events. Two extreme events were considered, one in 1997-2000, when Brazil's new water policy was very young, and the other one in 2012-2015. This analysis will be presented in more detail for the case of 
the Epitácio Pessoa reservoir, which suffered water crises in both periods.

\section{Results and discussion}

The Social-Ecological System Framework considered in the case study is: the resources systems are the river basins; the resources units are the reservoirs located in those basins; the uses are mainly the consumptive reservoirs' uses (urban and rural supply, irrigation and fisheries); and the Water Governance and Management System are defined by the Brazilian National Water Policy.

Considering the principle "clearly defined boundaries", the interactions between the governance system and users (reservoir users) were investigated, following the implementation of rules issued by water resources policies, the State Water Plan and other documents that deal with water permits, water quality (water body classification) and enforcement.

\subsection{Analysis of the Brazilian water governance}

Figure 2 presents how the principle "clearly defined boundaries" was identified in the National Water Policy of Brazil: it is established who has the right to use water, not only in rainy periods, but also in drought periods. Limits of the water resources were also identified: water permits are the instruments of the national water policy that aims to ensure the quantitative and qualitative control of water use. Water permits should be aligned with the classification of water bodies, which aims to ensure that water quality is compatible with their respective uses. The water permits are subject to the priorities of water usage established in the water resources plans (Federal Law 9433/97).

The granting of right to use water resources can be partly or fully suspended during disaster situations, including those resulting from adverse weather conditions. In situations of scarcity, the human and livestock consumption have priority over other uses (Federal Law 9433/97).

The reference discharges for the water reservoirs are established in the Paraíba State Water Plan (PERH), in 2006. It defines the water withdrawal limits from the reservoirs. The summation of all water permits for each reservoir most not exceed the reference discharge, to avoid overexploitation.

Regarding the classification of water bodies according to their water quality, bodies in the State of Paraíba were first classified in 1988 by the Environmental Council of Paraíba, before the water policy and management system have been instituted and implemented. The water bodies in this study were classified as Class 2: their water must comply with the standards for human consumption, after conventional treatment.

The National Water Agency (ANA) is responsible for the concessions of water permits and to enforce those boundaries, quantitative and qualitative, to the water users.

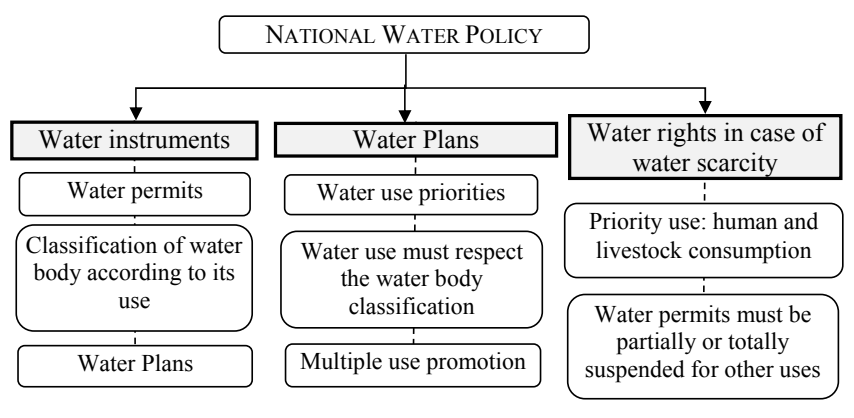

Figure 2. The relation between the National Water Policy and the principle "clearly defined boundaries".

\subsection{Analysis of the reservoir management}

As mentioned, the Paraíba State Water Plan presents the reference discharges of the reservoirs. In this topic, the reservoirs reference discharges were compared to observed withdrawals.

Table 1 shows some characteristics of four reservoirs, for the analysis of their management, in the first year of both drought periods (1997-2000 and 2012-2015). This evaluation showed significant differences between the observed withdrawal discharges and the reference discharges established by the Paraíba State Water Plan $\left(Q_{90}, Q_{95}\right.$ and $\left.Q_{100}\right)$. $Q_{x}$ is the monthly discharge with exceedance probability of $x \%$. The results shows a decline of reservoir withdrawals from 1997 ( $Q_{1997}$ ) to 2012 ( $Q_{2012}$ ). However, $Q_{90}, Q_{95}$ and $Q_{100}$ reference discharges are surpassed by $Q_{1997}$ and $Q_{2012}$ in most reservoirs.

Figure 3 shows the stored water volume of the reservoirs in the last 17 years. The graphs show a higher decline of the stored volume in the beginning of the drought periods, mainly related to the withdrawal discharges above established boundaries, the reference discharges. The reservoirs will reach their dead volume or will deplete in the second half of 2015, considering the persistence of the drought.

Veiga and Magrini (2013) presented an evaluation of the water instruments implementation in Brazil, where was identified that the water permits were implemented in the PPA Basin, location of Coremas/Mãe d'água, Engenheiro Ávidos and Lagoa de Arroz reservoirs. However, data from Table 1 and Fig. 3 clearly show that the water permits' instrument was not fully implemented for those reservoirs, since the absence of enforcement by the National Water Agency caused over exploitation of the water resources above the water permits.

It is important to mention that the water-permit discharge for urban supply from the Epitácio Pessoa Reservoir has a higher value than the established reference discharge in the State Water Plan $\left(Q_{100}\right)$. The water supply company for several cities around the reservoir is the only authorized user. Figure 4 shows, for this reservoir, the observed water storage and how the storage would decline if the boundaries of the 
Table 1. Comparisons between reservoir's withdrawals in $1997\left(Q_{1997}\right)$ and $2012\left(Q_{2012}\right)$ and reference discharges $Q_{90} / Q_{95} / Q_{100}$ established by the Paraíba State Water Plan (PERH).

\begin{tabular}{|c|c|c|c|c|c|c|c|c|c|}
\hline \multirow[t]{3}{*}{ Reservoir } & \multirow{3}{*}{$\begin{array}{l}\text { Capacity } \\
\left(\mathrm{hm}^{3}\right)\end{array}$} & \multicolumn{2}{|c|}{ Withdrawals } & \multirow[t]{2}{*}{$Q_{90} \mathrm{PERH}$} & \multirow[t]{2}{*}{$Q_{95}$ PERH } & \multirow[t]{2}{*}{$Q_{100}$ PERH } & \multirow[t]{2}{*}{$Q_{2012} / Q_{90}$} & \multirow[t]{2}{*}{$Q_{2012} / Q_{95}$} & \multirow[t]{2}{*}{$Q_{2012} / Q_{100}$} \\
\hline & & $1997-Q_{1997}$ & $2012-Q_{2012}$ & & & & & & \\
\hline & & & & $\left(\mathrm{m}^{3} \mathrm{~s}^{-1}\right)$ & & & & $(\%)$ & \\
\hline Coremas/Mãe d'Água & 1358 & 10.65 & 10.04 & 10.28 & 9.00 & 7.10 & 98 & 112 & 141 \\
\hline Epitácio Pessoa & 411 & 4.14 & 2.81 & 2.78 & 2.00 & 1.23 & 101 & 140 & 228 \\
\hline Engenheiro Ávidos & 255 & 1.59 & 1.50 & 2.47 & 1.96 & 1.45 & 61 & 76 & 103 \\
\hline Lagoa do Arroz & 80 & 1.55 & 0.99 & 0.73 & 0.60 & 0.43 & 136 & 165 & 231 \\
\hline
\end{tabular}

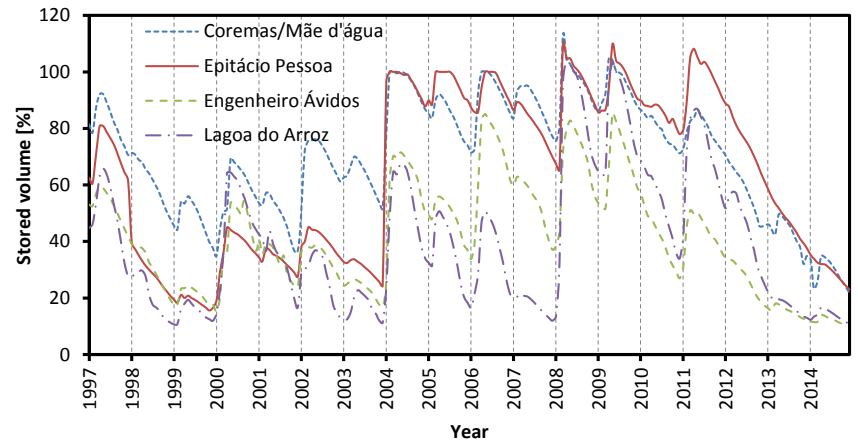

Figure 3. Stored water volume in percentage of full capacity, for the period 1997-2015, of the reservoirs Coremas/Mãe d'água, Engenheiro Ávidos, Lagoa de Arroz and Epitácio Pessoa (data source: AESA, 2015).

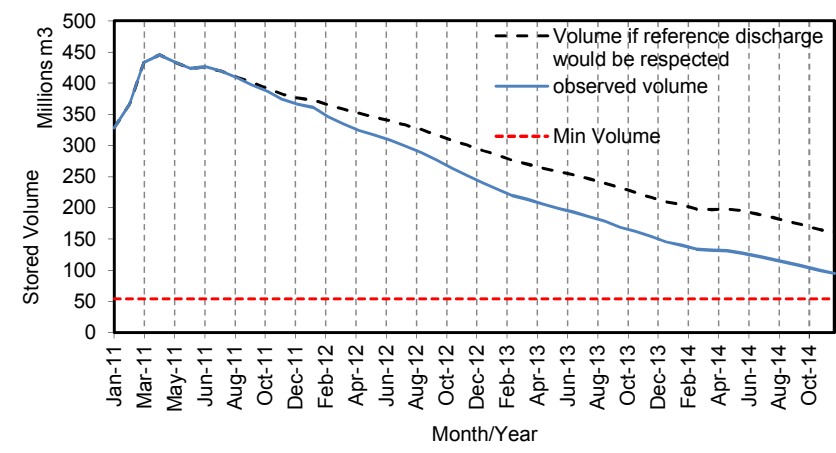

Figure 4. Observed and reference water storage of Epitácio Pessoa Reservoir (data source: AESA, 2015).

reference discharge would be respected. The reference water storage is obtained by the reservoir water balance, considering observed inflows, evaporation and the reference discharge established by the State Water Plan.

The relation between enforcement and water permits can be illustrated in the following specific case: the Epitácio Pessoa reservoir. The first enforcement campaign to control the water use of the reservoir, during the current drought, began in 2013, by the National Water Agency. During the enforcement campaigns many unauthorized water users were identified, most of them using water for irrigation. In addition, the water supply company withdrawal discharges greater than permitted.

Figure 5 presents the water's withdrawals from the Epitacio Pessoa reservoir. Withdrawals were obtained using the water balance of the reservoir, more precisely by calculating the daily water volume change in the reservoir and the daily reservoir evaporation to determine water withdrawals in the dry season. Highlighted in this figure are the relations between the enforcement campaigns in 2013 - the first on 14 May, the second on 5 July and the third on 19 August and short-time decreasing water withdrawals from the reservoir. The dotted line represents the trend of withdrawals using a polynomial regression of the observed values.

Those enforcement campaigns began in 2013, two years after the onset of the drought, and were not frequent. It is interesting to perceive how the water use increased just in few days after the campaigns. It shows the importance of permanent and continuous enforcement. Dietz et al. (2003) enlighten that enforcement mechanisms formal or informal, must be effective by those who should impose the rules and must be legitimate by resource users or resistance and evasion will overwhelm the commons governance strategy.

Figure 6 shows a false color satellite image of Epitácio Pessoa reservoir, from 7 October 2013 (Landsat 8). The blue area is the water surface of the reservoir and the area in light green refers to irrigated areas upstream in its surroundings. The irrigated areas around the reservoir were even higher before the inspection by ANA in May 2013.

The absence of enforcement also facilitates an uncontrolled water use of irrigation that might compromise the water quality by the use of toxic products in the proximities of the reservoir. An evaluation in 2002 showed that many pesticides, which were used in the irrigation sites could be carcinogenic and malefic for the human health. Pesticides are still not fully controlled around the reservoir.

In the end of 2014, after much negotiation, irrigation was finally forbidden. If the monitoring of water use had occurred properly, irrigators would have the opportunity to negotiate conflicts, to ensure water for multiple uses. The absence of water management discussions and enforcement led to the unauthorized use of water. The water supply company presents high leakage levels in the water distribution net- 


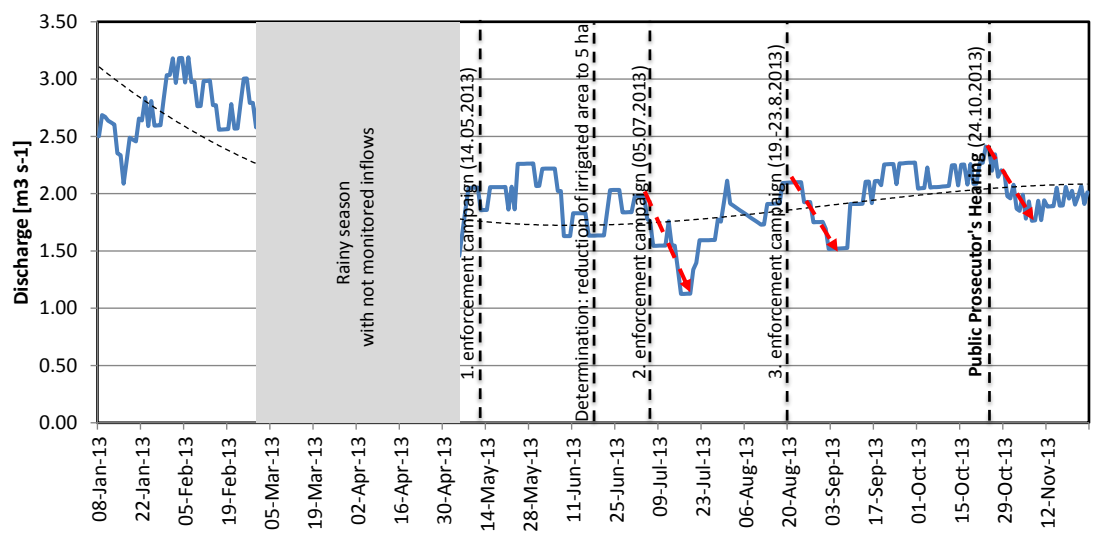

Figure 5. Relationship between reservoir water withdrawal for consumption from Epitácio Pessoa reservoir and enforcement campaigns.

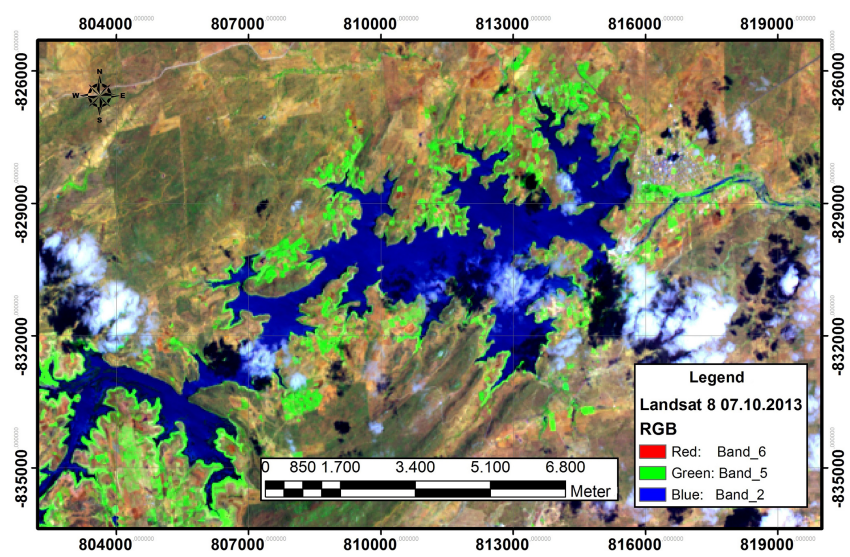

Figure 6. Satellite view of Epitácio Pessoa Reservoir and surroundings (7 October 2013) (LANDSAT 8, 2013).

work. It is important to enlighten that a permanent structure of supervision and enforcement was not yet implemented.

Galvão et al. (2001) presented the main reason of the first water crisis of Epitácio Pessoa Reservoir (1997-2000): inadequate management of water resources. The present analysis also shows the continuity of this inadequate management.

\section{Conclusions}

The effects of droughts might be influenced by water governance and management. Recognizing problems in water management and governance is one of the ways which have to be considered to overcome droughts and extreme events.

In this paper, the analysis of a SES considering Ostrom's principle "Clearly defined boundaries" showed that deficiencies in water management cause the intensification of droughts' impacts on the water users. On the other hand, the water users increase those impacts, through unauthorized withdrawals.
The analysis reinforces that understanding extreme events in a Social-Ecological Systems' perspective is relevant. An important factor is also the lack of transparency and accountability during the drought crisis. Therefore, it is important to review whether the rules of governance, such as water permits, have been properly followed in such social-ecological systems.

Acknowledgements. The authors acknowledge the support of the Brazilian agencies CAPES, CNPq and FINEP, as well as of the INCT-Clima Project, BRAMAR Project and REDE Clima.

\section{References}

AESA - Water Agency of the State of Paraiba: Monitoring of reservoir water levels in the State of Paraiba, AESA, Joao Pessoa, Brazil, 2015.

Anderies, J. M., Janssen, M. A., and Ostrom, E.: A framework to analyze the robustness of social-ecological systems from an institutional perspective, Ecol. Soc., 9, 18, 2004.

Dai, A.: Drought under global warming: a review, WIREs Climate Change, 2, 45-65, 2011.

Dietz, T., Ostrom E., and Stern, P. C.: The struggle to govern the commons, Science, 302, 1907-1912, 2003.

Galvão, C. O., Rêgo, J. C., Ribeiro, M. M. R., and Albuquerque, J. P. T.: Sustainability characterization and modelling of water supply management practices, in: Regional Management of Water Resources, edited by: Schumann, A., Acreman, M., Davis, R., Marino, M., Rosbjerg, D., and Jun, X., IAHS Press, IAHS Publ. 268, 81-88, 2001.

Huntjens, P., Lebel, L., Pahl-Wostl, C., Camkin, J., Schulze, L., and Kranz, N.: Institutional design propositions for the governance of adaptation to climate change in the water sector, Global Environ. Chang., 22, 67-81, 2012.

LANDSAT 8: Sensor OLI/TIRS Mosaic LC82150652013280LGN00: USGS EarthExplorer, NASA - USGS, 2013.

Ostrom, E.: Governing the Commons: The Evolution of Institutions for Collective Action, Cambridge University Press, Cambridge, UK, 1990. 
Ostrom, E.: Understanding Institutional Diversity, Princeton University Press, Princeton, USA, 2005.

Ostrom, E.: A Diagnostic Approach for Going Beyond Panaceas, P. Natl. Acad. Sci. USA, 104, 15181-15187, 2007.

Ostrom, E.: A General Framework for Analyzing Sustainability of Social-Ecological Systems, Science, 325, 419-422, 2009.

Silva, A. C. S.: Institutional analysis of water governance and adaptation to climate variability and change: a case study in the Brazilian semi-arid (1997-2013), PhD dissertation, Federal University of Campina Grande, Brazil, 2014 (in Portuguese).
Silva, A. C. S., Galvão, C. O., Silva, G. S., and Souza Filho, F. A.: Ostrom's institutional design principles and reservoir management: a study on adaptation to climate variability and change, in: Considering hydrological change in reservoir planning and management, edited by: Schumann A., Belyaev, V., Gargoury, E., Kuczera, G., Mahé, G., and Mallory, S., IAHS Press, IAHS Publ. 362, 101-106, 2013.

Veiga, L. B. E. and Magrini, A.: The Brazilian water resources management policy: fifteen years of success and challenges, Water Resour. Manag., 27, 2287-2302, 2013. 